the world economic space. The main purpose of studying a foreign language is formation and development of a communicative culture of pupils, training for the practical mastery of a foreign language.

The aim of the study. The purpose of teaching a foreign language at school is to lay the foundations of foreign language proficiency in junior pupils, that is to form the beginnings of phonetic, lexical, grammar, and spelling skills, as well as listening, speaking, reading and writing skills within the program requirements.

Research methods: theoretical (analysis of philosophical, pedagogical, psychological literature).

The effectiveness of innovative approaches to teaching foreign languages in the gymnasium will depend on the desire and ability of teachers to take advantage of the positive experience of domestic and foreign scientists and practitioners about the creative approach to learning, the understanding of the need to abandon authoritarian and scholastic methods. Innovative methods of teaching foreign languages, which are based on a creative approach, help to fully disclose the potential of pupils and promote development and selfimprovement of the educational and communicative process.

Key words: foreign language, gymnasium, education, pupil, teacher.

удк $378.14: 613$

Ірина Пальшкова

Південноукраїнський національний педагогічний університет імені К. Д. Ушинського

ORCID ID 0000-0002-6710-5232

DOI 10.24139/2312-5993/2020.10/379-391

\title{
СТАН ПІДГОТОВЛЕНОСТІ МАЙБУТНІХ УЧИТЕЛІВ ПОЧАТКОВИХ КЛАСІВ ДО ЗДОРОВ'ЯЗБЕРЕЖУВАЛЬНОЇ ДІЯЛЬНОСТІ
}

Стаття присвячена дослідженню проблеми підготовленості майбутніх учителів початкових класів до здоров'язбережувальної діяльності. На підставі аналізу загальних теоретичних підходів до змісту здоров'язбережувальної діяльності подано авторську позицію щодо визначеного конструкта. Розглянуто структуру підготовленості майбутніх учителів початкових класів до здоров'язбережувальної діяльності, яка складається з мотиваційно-когнітивної, операційно-коригувальної та оцінно-рефлексивної складових із показниками, відповідно до яких було дібрано мануал діагностувальних методик.

Ключові слова: майбутні вчителі початкових класів, здоров'язбережувальна діяльність, підготовленість, діагностика, складова, показники, констатувальний eman.

Постановка проблеми. Актуальність дослідження пов'язана 3 вирішенням пріоритетних завдань системи освіти у вихованні молодого покоління в дусі відповідального ставлення до власного здоров'я та оточуючих як найвищої індивідуальної суспільної цінності. За останні десятиліття в Україні ведеться активна робота з оновлення й удосконалення змісту початкової освіти (Закон України «Про вищу освіту», концепція «Нова українська школа», національна програма «Здоров'я через освіту»). 3 огляду на це одним із стратегічних напрямів реформування системи початкової 
освіти має бути створення в кожному навчальному закладі здоров'язбережувального освітнього простору, який забезпечить оптимальні умови для організації педагогічного процесу, усвідомлення сутності здоров'язбережувальної діяльності майбутніми вчителями та сприятиме збереженню їх здоров'я (Омельченко, 2017). Натомість аналіз робочих програм теоретичної та практичної підготовки здобувачів вищої освіти в педагогічних закладах засвідчив наявність низки суперечностей між: необхідністю цілеспрямованої підготовки майбутніх учителів початкових класів та недостатністю їі реалізації у процесі навчання в закладах вищої освіти; необхідністю підвищення якості організації здоров'язбережувальної діяльності майбутніми вчителями початкових класів та відсутністю відповідного навчально-методичного забезпечення цього процесу.

Аналіз актуальних досліджень. Слід зазначити, що дослідниками переважно розглядаються особливості організації формування окремих складників здорового способу життя студентської молоді (Н. Агаджанян, Г. Ахмерова, М. Бакшаєва, Є. Бондаревська, А. Боярський, О. Вакуленко, А. Гончаров, Б. Долинський, А. Дулевич, Л. Іващенко, С. Кондратюк, А. Ляхович, М. Носко, Л. Овчиннікова, В. Оржеховська, І. Пономаренко, Л. Розенфальд, Н. Рябова,Г. Серіков, В. Теслюкта ін.). Незважаючи на достатню кількість наукових досліджень, присвячених вивченню різноманітних аспектів підготовки майбутніх учителів початкових класів до професійної діяльності (К. Авраменко, Н. Бібік, Ю. Вавілова, М. Вашуленко, Н. Кічук, В. Ковальов, О. Комар, С. Литвиненко, О. Мельник, В. Полонський, О. Савченко, В. Сирота, Г. Тарасенко, Л. Фалько, Л. Хомич, І. Шапошникова та ін.), здоров'язбережувальним технологіям (В. Бондін, С. Грімблат, Ю. Кобяков, М. Смірнов та ін.), культурі здоров'я (В. Горащук, В. Зайцев, Л. Іванова, Г. Кривошеєва, В. Магін, С. Сімоненко, В. Скумін, І. Яковлева та ін.), питання цілеспрямованої підготовки їх до здоров'язбережувальної діяльності залишається відкритим.

Підготовка майбутніх учителів початкових класів повинна відповідати реаліям сьогодення, мета якого полягає у створенні психолого-педагогічних умов для розвитку індивідуальних здібностей, зміцненні здоров'я, формуванні здорового способу життя та реалізації базових потреб майбутніх учителів початкових класів не лише у спеціально організованому здоров'язбережувальному середовищі, але й у професійно-педагогічному просторі. Попри впровадження концептуальних засад Нової української школи в систему освіти, подальшого вивчення потребують науковометодологічні основи в напрямах підготовки майбутніх учителів початкової школи щодо здоров'язбережувальної діяльності. 
Мета та завдання дослідження. Метою статті $\epsilon$ висвітлення результатів підготовленості майбутніх учителів початкових класів до здоров'язбережувальної діяльності на констатувальному етапі експерименту. Завданням означеного етапу дослідження $€$ визначення складових і показників підготовленості майбутніх учителів початкових класів до здоров'язбережувальної діяльності та їх діагностика.

Методи дослідження. Для визначення рівнів підготовленості майбутніх учителів початкових класів до здійснення здоров'язбережувальної діяльності було використано: анкетування з метою визначення стану обізнаності здобувачів вищої освіти з напрямами здоров'язбережувальної діяльності; картки самооцінки обізнаності здобувачів вищої освіти із сутністю здорового способу життя засобами здоров'язбережування, видами особистісного здоров'я (розроблені автором); методика КОС-1 використовувалася для визначення рівнів сформованості комунікативних і організаторських здібностей (В. Синявський, В. Федоришин), методики визначення наявності проєктивних і аналітичних умінь (розроблені автором); тест «Діагностика лідерських здібностей (Е. Жаріков, Е. Крушельницький) для визначення рівня вираженості лідерських якостей; для визначення рівня сформованості морально-вольових якостей (методика А. Вострікова та Н. Кузьміної).

Виклад основного матеріалу. Аналіз вищезазначених наукових доробок дав змогу встановити, що недостатньо вивченими аспектами проблематики формування здоров'я залишаються її термінологічний апарат, методичні й методологічні засади здоров' язбережувальної діяльності в освіті. Разом із тим, вітчизняний науковий простір наповнюється розвідками, в яких декларується, що найбільш оптимальними для визначення галузі педагогічної науки, яка вивчає стан і розвиток теорії та практики навчання основ здоров'я та виховання у здоров'ї на різних етапах людського життя, вважають терміни «педагогіка здоров'я», «здоров'ятворча педагогіка», «здоров'язбережувальна освіта», «превентивна педагогіка», «здоров'язбережувальна педагогіка» (Сливка, 2016). Прикладом цьому $є$ дослідження О.Карпусь, у якому авторкою розглянуто термінологічний інструментарій щодо проблеми здоров'язбереження та наголошено на тому, що більшість сучасних країн світу значну увагу приділяє здоров'язбереженню свого населення, адже процвітання нації залежить від стану здоров'я жителів країни, їх налаштування на здоровий спосіб життя й особисту відповідальність за власне здоров'я та здоров'я оточуючих (Карпусь, 2020).

На підставі вивчення сутності професійно-педагогічної діяльності вчителів початкових класів у загальноосвітніх закладах з'ясовано, що вона 
охоплює різноманітні напрями: організацію роботи, спрямовану на збереження та зміцнення здоров'я дітей; організацію навчально-виховної діяльності, спрямованої на валеологічне виховання учнів; надання допомоги дітям відчувати себе суб'єктом здоров'язбережувальної діяльності; розвивати в учнів уміння самооцінки функціонального стану організму; створення мотивації до ведення та пропагування здорового образу життя тощо.

Проведені довготривалі спостереження й бесіди з учнями, батьками, вчителями, адміністрацією загальноосвітніх закладів дозволили дійти висновку, що здоров'язбережувальна діяльність $\epsilon$ досить важливою ланкою освітнього процесу в сучасній школі. Організація такої роботи повинна бути спрямована на: підвищення індивідуального потенціалу здоров'я; сприяння емоційно-ціннісному ставленню до власного здоров'я; формування навичок, що сприяють збереженню фізичного, психічного, морального, соціального, здоров'я; формуванню гуманістичного стилю спілкування учасників освітнього процесу зокрема.

Зауважимо, що на сьогодні не існує єдиного підходу до розуміння сутності здоров'язбережувальної діяльності та підготовленості майбутніх учителів початкових класів до неї. у наукових джерелах здоров'язбережувальна діяльність трактується як: організація життя людини, що передбачає гармонізоване використання й розвиток її духовно-моральних і фізичних сил, виховання прагнень до збереження індивідуального й соціального здоров'я, формування уявлень про шкідливість алкоголю, паління та наркотиків (Звєкова, 2009); цілісний і багатогранний процес, який спрямований на перетворення інтелектуальної та емоційної сфер особистості студента, підвищення ціннісного ставлення як до власного здоров'я, так і до здоров'я школярів на підставі усвідомлення студентом власної відповідальності (Сентизова, 2008); багатофункціональне соціальне явище, що передбачає впровадження здоров'язберігаючих технологій шляхом застосування відповідних методів і засобів організації навчально-виховного процесу, які не зашкоджують здоров'ю дітей та спрямовані на формування здоров'язберігаючих навичок і вмінь, що сприяють збереженню фізичного, психічного, соціального, морально-духовного здоров'я учасників навчальновиховного процесу (Долинський, 2010).

Розглядаючи сутність здоров'язбережувальної діяльності майбутнього вчителя початкової школи, зауважимо на дослідженні Б. Долинського, в якому визначено такі методологічні підходи, на яких ґрунтується процес підготовки здобувачів вищої освіти майбутніх учителів початкових класів до неї з молодшими школярами в освітньому процесі, як-от: аксіологічний, 
системний, особистісно-діяльнісний та культурологічний. Так, аксіологічний підхід у процесі підготовки майбутніх учителів початкової школи передбачає сформованість у них системи соціально-спрямованого ціннісного ставлення до духовних та матеріальних засобів у формуванні здорового способу життя; їхню здатність реально та об'єктивно оцінювати свої фізичні, психоемоційні, духовні, соціальні можливості; розуміння здоров'я та фізичної досконалості людини як практичної, соціальної, особистісної, національної, етичної та загальнолюдської цінності, що виявляється в усвідомленні необхідності дотримуватися здорового способу життя, що дозволить найбільш повно здійснити завдання здоров'язбереження свого й учнів у майбутній професійній діяльності. Системний підхід передбачає взаємодію між здобувачами вищої освіти й викладачами в різних видах діяльності: навчальній (взаємодія валеологічної освіти з дисциплінами гуманітарного, соціально економічного, природничо-наукового, професійного та практичного циклів фахової підготовки майбутніх учителів початкової школи), виховній (позааудиторна виховна робота, що передбачає організацію та проведення фізкультурно-спортивних змагань, творчих конкурсів, спортивних свят), самостійній (організація пошукової та дослідницької діяльності студентів із питань здоров'язбереження, самостійні заняття фізичною культурою та спортом (спортивні секції, гуртки), застосування одержаних знань і вмінь під час педагогічної практики з урахуванням збереження та зміцнення здоров'я молодших школярів. Забезпечення системного підходу, спрямованого на збереження та зміцнення здоров'я майбутніх учителів початкової школи під час навчання в педагогічному закладі вищої освіти, сприятиме їхній підготовці до здійснення здоров'язбережувальної діяльності в умовах початкової школи. Культурологічний підхід у підготовці майбутніх учителів початкових класів до здоров'язбережувальної діяльності дозволяє виокремити в контексті дослідження сукупність таких культурних компонентів, як педагогічна, фізична, валеологічна, екологічна культура, культура здоров'я, які становлять здоров'язбережувальний культурний напрям. Особистісно-діяльнісний підхід в аспекті дослідження передбачає спрямованість процесу підготовки майбутніх учителів початкових класів на здобуття знань, умінь і навичок щодо організації різноманітної діяльності (навчально-виховної, спортивно-ігрової, фізкультурно-оздоровчої, дозвіллєвої, просвітницько-валеологічної та ін.), яка 6 не зашкоджувала їхньому здоров'ю та здоров'ю учнів (Долинський, 2010).

Урахування означених підходів викликає необхідність у більш детальному розгляді усвідомлення майбутніми вчителями наукової 
зорієнтованості та змістового наповнення конструктів «індивідуальне здоров'я особистості», «здоровий спосіб життя», «засоби здоров'язбереження» ще під час здобуття вищої освіти.

Теоретичний аналіз наукового фонду (Є. Бондаревська, Л. Іващенко, Н. Страпко, Л. Хомич, С. Шмалєй та ін.) з означеної проблематики дав змогу диференціювати якісну структуру діяльності здобувачів вищої освіти 3 основ формування здорового способу життя, виявити специфіку взаємоузгодження її складників у підтриманні рівня здоров'я. На думку вчених, формування здорового способу життя має зводитися до дотримання таких вимог, як: регулярний сон, особиста гігієна, урахування основ раціонального харчування, виконання моральних норм, відсутність шкідливих звичок, профілактичні медогляди тощо (Шмалєй, 2005).

Зважаючи на те, що сучасна підготовка здобувачів вищої освіти повинна відповідати вимогам Болонської декларації, слушним є дослідження В. Андрущенко, в якому індивідуальне здоров'я особистості містить такі складові, як: психічне, фізичне, морально-духовне, соціальне та професійне здоров'я. Так, психічне здоров'я розглядається як сукупність настанов, якостей і функціональних здібностей майбутніх учителів, що дозволяє їм адаптуватися до довкілля та $є$ необхідним у професійній діяльності. Фізичне здоров'я забезпечується позитивним ставленням до нього як до загальнолюдської цінності, достатньою руховою активністю, раціональним харчуванням, дотриманням санітарно-гігієнічних навичок, а також визнанням необхідності занять фізкультурно-оздоровчими, спортивно-ігровими вправами, що сприятимуть не лише формуванню в майбутніх учителів здоров'язбережувальних умінь і навичок, зміцненню їхнього фізичного здоров'я, але й набуттю вмінь організовувати відповідну здоров'язбережувальну діяльність.

Під морально-духовним здоров'ям автор розуміє наявність у майбутніх учителів системи цінностей, настанов і мотивів їхньої поведінки у професійній діяльності, що передбачає формування відповідних здоров'язбережувальних навичок і вмінь, спрямованих на розвиток високої духовності особистості та пов'язаних із такими загальнолюдськими цінностями, як добро, любов, краса тощо. Науковець також вважає, що морально-духовне здоров'я $€$ передумовою самоствердження здобувачів вищої освіти в суспільстві та професійно-педагогічній діяльності зокрема.

Соціальне здоров'я передбачає наявність у майбутніх учителів сформованих знань, умінь і навичок спілкування (з дітьми, їхніми батьками, колегами, адміністрацією). Рівень сформованості цього виду 
також впливає на соціальну поведінку в професійній діяльності та соціумі, відповідає нормам, які ставить суспільство до вчителя. Професійне здоров'я учителя, на думку автора, необхідно визначати як цілісний багатомірний динамічний стан організму, який дозволяє освітянам максимально реалізовувати свій творчий потенціал у професійнопедагогічній діяльності (Андрущенко, 2004).

Розглядаючи засоби здоров'язбереження, вважаємо за необхідне наголосити на фізичних вправах як повторному здійсненні різних видів рухових дій, що активізують низку життєвих процесів. Як справедливо наголошує М.Смірнов, якісне різноманіття методів фізичного виховання визначає спосіб повторення фізичних вправ, які диференціюють так: просте повторення рухів і накопичення ефекту вправи лежать в основі виховання фізичних здібностей; модифіковане повторення й відбір - в основі навчання рухів; кодове повторення $є$ основою формування органів чутя й інтелекту, виховання здатності до високих меж сприйняття й обробки інформації; модельне повторення - умови нормування тактичних здібностей, умінь найбільш раціонально діяти в новій обстановці. Формування свідомості, моральних, вольових та емоційних якостей ґрунтується на конспективному повторенні й узагальненні, які припускають повторення у граничному стислому вигляді основних ступенів формування суспільної свідомості. У свою чергу, засвоєння норм моралі, етики й естетики припускає розгорнуте їх повторення в конкретних формах поведінки під час рухової діяльності. До форм предметно-методичної організації процесу вправи, що історично склалися, відносять такі способи в різних поєднаннях як: мимовільні, імітаційно-ігрові, природничо-прикладні, аналітичні, спортивні та комплексні (Смірнов, 2003).

Відтак, спираючись на вищезазначене, для здійснення означеної діяльності майбутні вчителі початкових класів повинні бути підготовленими. Під підготовленістю майбутніх учителів початкових класів до здоров'язбережувальної діяльності розуміємо індивідуальне інтегроване утворення, що характеризується наявністю: сформованості практичних умінь і навичок для організації та здійснення ії 3 використанням засобів здоров'язбереження, враховуючи валеологічні принципи; розвинених особистісних якостей і необхідних теоретичних знань щодо сутності основ індивідуального здоров'я особистості та здорового способу життя.

У структурі підготовленості майбутніх учителів початкових класів до здоров'язбережувальної діяльності виокремлюємо мотиваційно-когнітивну (усвідомлення цінності здоров'я та система знань, необхідних для вирішення здорового способу життя), операційно-коригувальну (передбачає 
сформованість загально-методичних і спеціальних умінь, що уможливлюють якісне виконання здоров'язбережувальної діяльності) та оцінно-рефлексивну (передбачає здатність здійснювати аналіз, самоаналіз і оцінювання результатів здоров'язбережувальної діяльності) складові. Так, мотиваційнокогнітивна складова підготовленості майбутніх учителів початкових класів до здоров'язбережувальної діяльності оцінювалася за такими показниками: позитивна мотиваційна спрямованість щодо здоров'язбережувальної діяльності; обізнаність із напрямами здоров'язбережувальної діяльності. Стан підготовленості майбутніх учителів початкових класів до здоров'язбережувальної діяльності за операційно-коригувальною складовою діагностувався за такими показниками, як-от: наявність комунікативноорганізаторських, проєктувальних, аналітичних умінь та морально-вольових якостей. Рівні підготовленості майбутніх учителів початкових класів до здоров'язбережувальної діяльності за оцінно-рефлексивною складовою оцінювалися за такими показниками, як наявність здатності до педагогічної рефлексії та вмінь адекватного оцінювання ії результатів.

Для визначення рівнів підготовленості майбутніх учителів початкових класів до здоров'язбережувальної діяльності було обрано діагностику, у якій на підставі вивчення ступеня прояву ознак запропонованих показників респондентів було віднесено до достатнього, задовільного чи низького рівня.

Так, достатній рівень підготовленості майбутніх учителів початкових класів до здоров'язбережувальної діяльності був характерний здобувачам вищої освіти, які мають глибокі й міцні знання щодо її специфіки, варіативності іiі напрямів. Вони обізнані з науковим підґрунтям індивідуального здоров'я особистості, здорового способу життя та здоров'язбережувальних засобів. У таких здобувачів вищої освіти на достатньому рівні сформовані комунікативні та організаторські вміння, вони виявляють виражені лідерські якості, вирізняються самокритичністю, дисциплінованістю, почуттям відповідальності за інших людей. Вони вміють проєктувати здоров'язбережувальну діяльність, точно та правильно аналізувати й оцінювати їі, контролювати свій емоційний стан і цілком адекватно реагують на вчинки оточуючих, не виявляють конфліктності у стосунках із ними.

Задовільний рівень підготовленості майбутніх учителів початкових класів до здоров'язбережувальної діяльності характерний для здобувачів вищої освіти, у яких знання щодо специфіки такої діяльності та варіативності їі напрямів $€$ епізодичними. Такі здобувачі вищої освіти недостатньо вміло використовують одержані знання на практиці, відчувають труднощі у проєктуванні здоров'язбережувальної діяльності. у 
них недостатньо сформовані комунікативні та організаторські вміння, вони не виявляють лідерських якостей, не завжди вирізняються самокритичністю, дисциплінованістю, почуттям відповідальності за інших людей. Вони відчувають труднощі в організації здоров'язбережувальної діяльності, припускаються помилок під час їі аналізу. Таким здобувачам притаманне неадекватне реагування на вчинки довколишніх людей. Вони іноді виявляють конфліктність у стосунках з оточуючими.

Низький рівень підготовленості майбутніх учителів початкових класів до здоров'язбережувальної діяльності характерний для пасивних у навчанні здобувачів вищої освіти, які мають нечітке уявлення про ії специфіку, варіативність ії напрямів, не прагнуть до здорового способу життя, не усвідомлюють ролі індивідуального здоров'я в особистому житті та сутність здоров'язбережувальних засобів. у таких студентів несформовані комунікативні та організаторські вміння, їм важко впроваджувати здобуті знання у практичну діяльність, вони не виявляють лідерських якостей, несамокритичні, недисципліновані, невідповідальні за інших людей. Стосунки з довколишніми людьми здебільшого мають негативний характер. Такі здобувачі вищої освіти часто вступають у конфлікт, не вміють налагоджувати стосунки з оточуючими.

У констатувальному етапі експерименту взяли участь 42 здобувачі вищої освіти факультету початкового навчання Державного закладу «Південноукраїнський національний педагогічний університет імені К. Д. Ушинського». Висвітлимо результати підготовленості майбутніх учителів до професійної діяльності за визначеними показниками на констатувальному етапі експерименту.

Достатній рівень позитивної мотиваційної спрямованості на здоров'язбережувальну діяльність (перший показник мотиваційно-когнітивної складової) виявили 15,1\% респондентів (засвідчили ії на рівні професійної потреби), базовий - 61,2% (домінували мотиви допитливості), низький $23,7 \%$ респондентів (епізодична зацікавленість). За другим показником означеної складової встановлено, що лише 13,9\% респондентів правильно розуміють сутність здоров'язбережувальної діяльності вчителя початкових класів, вони обізнані з напрямами здорового способу життя. Базовий рівень засвідчила переважна більшість респондентів - 61,9\% (вони мали певні уявлення про сутність поняття «здоров'язбережувальна діяльність», називали різні змістовні ознаки за видами здоров'я), 24,2\% респондентів виявили низький рівень (не розуміли сутності поняття «здоров'язбережувальна діяльність», називали лише деякі засоби здоров'язбереження). 
За першим показником операційно-коригувальної складової здоров'язбережувальної діяльності з'ясовано, що організаційні вміння (здатність швидко й ефективно встановлювати соціальні контакти, впливати на довколишніх, стимулюючи їх до певного виду діяльності, швидко й відповідно до ситуації приймати рішення, виявляти ініціативу тощо) на достатньому рівні сформовано у 28,4\%, базовому - у 58,7\%, низькому - у 12,9\% від загальної кількості респондентів. Водночас, за другим показником сформованості морально-вольових якостей цієї складової на достатньому рівні було діагностовано 13,7 \%, на базовому 62,6 \%, на низькому - 23,7 \% від загальної кількості респондентів.

Достатній рівень сформованості здатності до педагогічної рефлексії (перший показник оцінно-рефлексивної складової) засвідчили 14,3%, базовий - 70,5 \%, низький - 15,2 \% респондентів. Здатність до адекватного оцінювання результатів здоров'язбережувальної діяльності (другий показник означеної складової) на достатньому рівні сформована у $21,4 \%$ респондентів, 56,7\% респондентів здійснювали таку діяльність на базовому, а 21,9 \% респондентів - на низькому рівні.

Значення кожної зі складових підготовленості майбутніх учителів початкових класів до здоров'язбережувальної діяльності здобувалось обчисленням середнього арифметичного за відповідними показниками, що подано в таблиці 1.

Таблиця 1

Результати діагностики рівнів підготовленості майбутніх учителів початкових класів до здоров'язбережувальної діяльності

\begin{tabular}{|l|l|l|l|}
\hline \multirow{2}{*}{ Складові } & \multicolumn{3}{c|}{ Рівні підготовленості у \% } \\
\cline { 2 - 4 } & достатній & базовий & низький \\
\hline Мотиваційно-когнітивна & 14,5 & 61,55 & 23,95 \\
\hline Операційно-коригувальна & 21,05 & 60,65 & 18,3 \\
\hline Оцінно-рефлексивна & 17,85 & 63,6 & 18,55 \\
\hline Середнє значення & 17,8 & 61,9 & 20,3 \\
\hline
\end{tabular}

Як бачимо з таблиці 1, за мотиваційно-когнітивною складовою підготовленості майбутніх учителів початкових класів до здоров'язбережувальної діяльності достатній рівень засвідчили 14,5\% респондентів, базовий - 61,55 \%, низький рівень - 23,95 \% від загальної кількості здобувачів вищої освіти. Достатній рівень за операційнокоригувальною складовою засвідчили 21,05\% респондентів, базовий - 
$60,65 \%$, низький - 18,3\% здобувачів вищої освіти. Результати оціннорефлексивної складової виявилися такими: достатній рівень - 17,85 \%, базовий - 61,9 \%, низький - 20,3 \% здобувачів вищої освіти.

Узагальнені результати підготовленості майбутніх учителів початкових класів до здоров'язбережувальної діяльності унаочнено на рисунку 1.

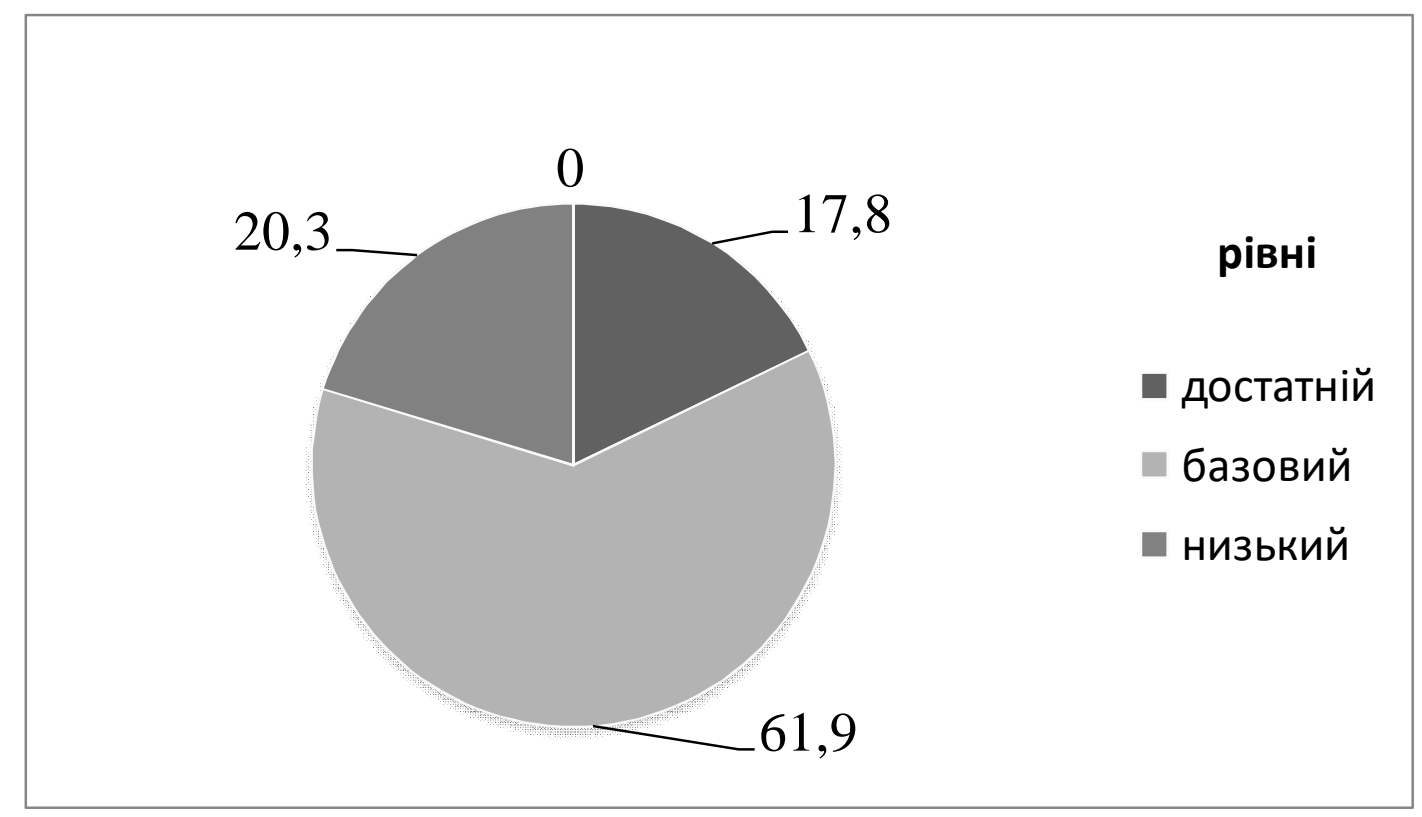

Рис. 1. Загальні рівні підготовленості майбутніх учителів початкових класів до здоров'язбережувальної діяльності (констатувальний етап), у \%

Отже, як видно з рисунку 1, найбільша кількість майбутніх учителів початкових класів (61,9\%) засвідчила базовий рівень підготовленості до здоров'язбережувальної діяльності. На достатньому рівні виявлено меншість майбутніх учителів початкових класів - 17,8 \%. На низькому рівні підготовленості до здоров'язбережувальної діяльності опинилися 20,3% від загальної кількості майбутніх учителів.

Висновки. Аналіз одержаних упродовж констатувального етапу педагогічного експерименту результатів свідчить про необхідність подальшої роботи щодо підготовки майбутніх учителів початкових класів до здоров'язбережувальної діяльності. Саме тому перспективу подальших наукових розвідок убачаємо в розробленні експериментальної методики підготовки майбутніх учителів початкових класів до здоров'язбережувальної діяльності.

\section{ЛІТЕРАТУРА}

Андрущенко, В. П. (2004). Педагогічна освіта України в стратегії Болонського процесу. Освіта України, 1, 5-9. (Andrushchenko, V.P. (2004).Pedagogical education of Ukraine in the strategy of the Bologna process. Education of Ukraine, 1, 5-9). 
Долинський, Б. Т. (2010). Методологія здоров'язберегаючої діяльності майбутнього вчителя початкової школи. Одеса: Видавець М. П. Черкасов. (Dolynsky, B.T. (2010). Methodology of health-preserving activity of the future primary school teacher. Odessa: Publisher M.P. Cherkasov).

Звєкова, В.К. (2009). Підготовка майбутніх учителів до організації здоров'язберігаючого дозвілля школярів (дис. ... канд. пед. наук: 13.00.04). Ізмаїл (Zvekova, V.K. (2009).Preparation of future teachers for the organization of pupil's healthy-preserving leisure (PhD thesis). Ishmael).

Карпусь, О. (2020). Термінологічний інструментарій дослідження проблеми здоров'язбереження у Фінляндії. Педагогічні науки: теорія, історія, інноваційні технології, № 1 (95), 11-8. (Karpus, 0. (2020). Terminological tools for the research on health in Finland. Pedagogical sciences: theory, history, innovative technologies, № 1 (95), 11-18).DOI 10.24139/2312-5993/2020.01/012-019

Омельченко, С. О. (2017). Здоров'язбережувальний освітній простір як основа ефективності функціонування сучасного навчального закладу. Глобальні виклики педагогічної освіти в університетському просторі: матеріали III Міжнародного Конгресу (м. Одеса, 18-21 травня 2017 року). Одеса: Видавничий дім «Гельветика», сc. 18-19. (Omelchenko, S.O. (2017). Health-preserving educational space as a basis for the effective functioning of a modern educational institution. Global challenges of pedagogical education in the university space: materials of the III International Congress (Odessa, May 18-21, 2017). Odessa: Helvetica Publishing House, 18-19).

Сентизова, М. И. (2008). Педагогическое обеспечение підготовки будущих учителей к здоровьесберегающей деятельности (автореф. дис. ... канд.пед. наук: 13.00.01). Якутск. (Sentizova, M. І. (2008). Pedagogical support of the future teachers'preparation for health-preserving activity (DSc thesis abstract). Yakutsk.

Сливка, Л. В. (2016). Здоров'язбережувальна педагогіка. Івано-Франківськ: видавець Кушнір Г. М. (Slivka, L.V. (2016). Health-preserving pedagogy. Ivano-Frankivsk: publisher Kushnir G.M.).

Смирнов, Н. К. (2003). Здоровьесберегающие образовательные технологии в работе учителя школы. М.: АРКТИ. (Smirnov, N. K. (2003). Health-preserving educational technologies in the work of a schoolteacher.M.: ARKTI).

Шмалєй, С. В., Ханзельдієва, Ш. (2005). Валеологічний супровід освітнього процесу в навчальному закладі. Вісник Чернігівського педагогічного університету імені Т.Г. Шевченка. Психологічні науки, 31, Т. 3, 178-183. (Shmalei, S. V., Hanzeldieva, Sh. (2005). Valeological support of the educational process in the educational institution. Bulletin of Chernihiv Taras Shevchenko Pedagogical University.Psychological Sciences, 31, V. 3, 178-183).

\section{PEЗЮМЕ}

Пальшкова Ирина. Состояние подготовленности будущих учителей начальных классов к здоровьесохраняющей деятельности.

Статья посвящена исследованию проблемы подготовленности будущих учителей начальных классов к здоровьесохраняющей деятельности. На основании анализа общих теоретических подходов к содержанию здоровьесохраняющей деятельности представлена авторская позиция относительно выделенного конструкта. Рассмотрена структура подготовленности будущих учителей начальных классов к здоровьесохраняющей деятельности, состоящий из мотивационно-когнитивной, операционно-корректирующей и оценочно- 
рефлексивной составляющих с показателями, согласно которым был подобран мануал диагностирующих методик.

Ключевые слова: будущие учителя начальных классов, здоровьесохраняющая деятельность, подготовленность, диагностика, составляющая, показатели, констатирующий этап.

\section{SUMMARY}

Palshkova Iryna. The state of preparedness of future primary school teachers for health-preserving activity.

Improving the quality of primary education is an important task of the current stage of Ukrainian society development, the implementation of which is primarily related to the training of future professionals who can create psychological and pedagogical conditions for developing students's individual abilities, strengthening of their health, forming their healthy lifestyle and realization of the basic needs of younger generation not only in a specially organized health environment, but also in the professional and pedagogical area. This task fully meets the requirements of the State Standard of Primary Education in Ukraine, documents and the project "New Ukrainian School", which regulate the functioning and modern guidelines for the development of primary and higher education in Ukraine in the XXI century. Under these conditions preparing of future primary school teachers for healthpreserving activities is of paramount importance.

The aim of the article is to highlight and analyze the results of the diagnosis of the future primary school teachers' readiness for health care activities at the ascertaining stage of the experiment. Preparing the future primary school teachers for health care is understood as individual integrated quality, characterized by the practical skills for the organization and activity implementation with the use of health care means, based on valeological principles; developed personal qualities and the necessary theoretical knowledge based on the essence of individual health and healthy lifestyle. The structure of preparation of future primary school teachers for health care activities consists of motivational-cognitive, operationalcorrective and evaluation-reflexive components with the indicators according to which the manual of diagnostic methods was selected.

During the ascertaining stage of the experiment the sufficient level of readiness for the activity mentioned was demonstrated by $14.5 \%$, the basic one - by $59.7 \%$ and the low one - by the $25.8 \%$ of future primary school teachers.

Key words future primary school teachers, health-preserving activities, preparedness, diagnosis, component, indicators, ascertaining stage.

\section{удк 378}

\section{Наталія Пилюк \\ Східноєвропейський національний університет імені Лесі Українки ORCID 0000-0002-5500-3044 \\ DOI 10.24139/2312-5993/2020.10/391-400 \\ ДІЯЛЬНІСТЬ СОЦІАЛЬНОГО ПЕДАГОГА 3 РЕАЛІЗАЦІї ЗДОРОВ'ЯЗБЕРЕЖУВАЛЬНИХ ТЕХНОЛОГІЙ В ОСВІТНЬОМУ СЕРЕДОВИЩІ}

у статmі розглянуто діяльність соціального педагога $з$ реалізації здоров'язбережувальних технологій в освітньому середовищі. Розкрито різні підходи до трактування понять «здоров'язбереження», «здоров'язбережувальні технології». Зазначено, що здоров'язбережувальні технології є системою, яка створює максимально 